\title{
George Martin Baer (1936-2009): in memoriam
}

\author{
Frederick A. Murphy · Charles E. Rupprecht • \\ Brian W. J. Mahy $\cdot$ Leland E. Carmichael
}

Received: 24 June 2010/ Accepted: 17 September 2010

(C) Springer-Verlag 2010

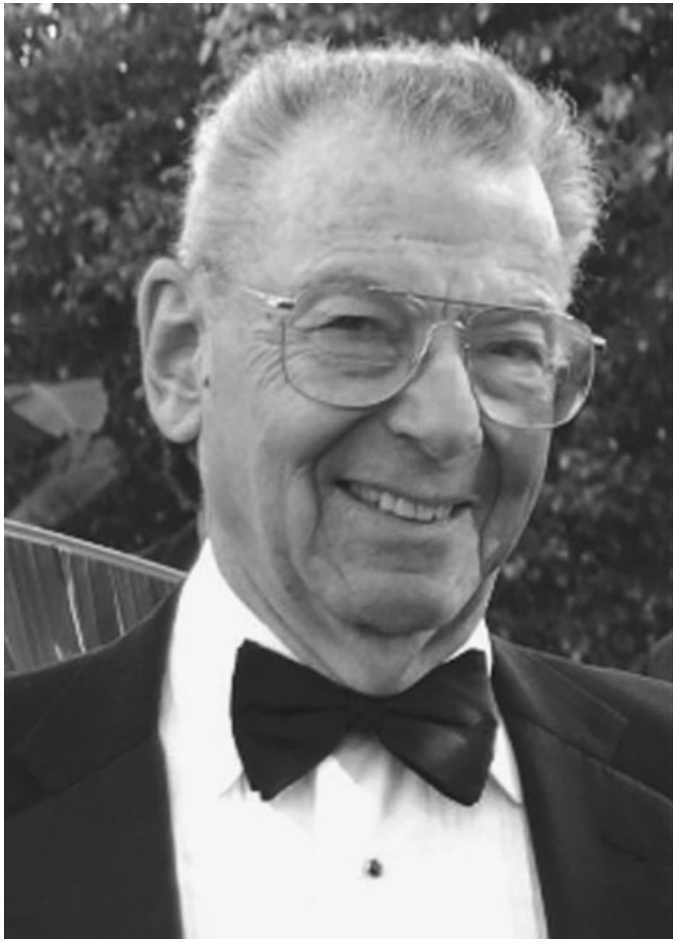

Respectfully submitted on behalf of George's many friends and colleagues.

\footnotetext{
F. A. Murphy $(\bowtie)$

Department of Pathology, University of Texas Medical Branch, Route 0609, 301 University Blvd, Galveston, TX 77555-0609, USA

e-mail: famurphy@utmb.edu

C. E. Rupprecht - B. W. J. Mahy

Centers for Disease Control and Prevention, Atlanta, Georgia

L. E. Carmichael

Cornell University, Ithaca, New York
}

George Martin Baer, one of the world's most distinguished rabies experts, and a dear friend of many colleagues around the world, died on June 2, 2009, in Mexico City, at the age of 73. He is survived by his beloved wife, Maria Olga, three daughters, Katherine, of Washington, D.C., Alexandra, of New Paltz, New York, and Isabella, of Mexico City, and four granddaughters. Funeral services were held in Mexico City at the Iglesia de Santa Rosa de Lima on June 4, 2009.

George was the only son of Kathi Meyer Baer, of Berlin, and Curtis Otto Baer, of Strasbourg, France (then Strassburg, Germany). His mother was a renowned musicologist and his father was a noted collector of 18th and 19th century master drawings and paintings. George was born in 1936 in London. In 1938, George's parents fled Nazi Germany and in 1940 emigrated to the United States. George grew up in New Rochelle, New York, where he became an accomplished equestrian, and began a lifelong love of animals. He attended Cornell University, where he obtained an undergraduate degree in agricultural sciences in 1954, and a doctor of veterinary medicine degree in 1959. He earned a Master's degree in public health from the University of Michigan at Ann Arbor in 1961.

George was then commissioned as a U.S. Public Health Service officer, joining the Epidemiology Intelligence Service (EIS) of the Centers for Disease Control and Prevention (CDC). He was assigned to the New York State Department of Health in Albany, where he worked on brucellosis and psittacosis, and began his life-long passion for rabies, especially the development of practical means for its prevention and control.

In 1964, he was assigned as director of CDC's Southwest Rabies Investigations Laboratory in Las Cruces New Mexico. The focus of his work in Las Cruces was on bat rabies. From 1966 to 1969 , he served as a consultant to the Pan American Health Organization in Mexico, where he 
served as chief of the Microbiology Department in Palo Alto. There he continued his work on the development of rabies prevention and control programs at the local, regional and national level. It was during this first assignment in Mexico that George initiated the groundwork for Mexico's national rabies prevention and control program, work that he continued throughout his professional life, with great success. Proof of his success, and that of the veterinary public health agencies of Mexico, is seen in the spectacular reduction in the incidence of rabies in humans and domestic animals over recent years. This success spread to all of Central and South America, again based upon the principles and practices pioneered by George in Mexico.

In 1969, George returned to Georgia, where he became chief of the CDC Rabies Laboratory in Lawrenceville, about 20 miles from the main CDC campus. The Rabies Laboratory had initially been set up to test domestic animal rabies vaccines, so there was a facility for housing hundreds of dogs. Much of what was learned about the safety and efficacy of a diverse set of rabies vaccines came from studies done in that facility by George and his staff. These were the days when classical Pasteurean vaccines had given way to attenuated live-virus vaccines (e.g., LEP, HEP), inactivated vaccines produced in embryonating duck eggs, the first cell culture vaccine substrates, and even suckling mouse brain. At the same time, George and his staff did seminal work on rabies virus pathogenesis, most interestingly showing how rabies virus moves from the site of its entry into the body in the bite of a rabid animal, to the brain via infection of nerves (neurons, nerve fibers). This was done by interrupting nerve fibers in the leg at varying times after virus introduction in the foot. When nerves were severed the course of the infection was halted. This work offered the first sound explanation of the usual success of post-exposure prophylaxis.

With the staff of the CDC Rabies Laboratory, George developed the concept of wildlife rabies control via immunization of reservoir animal species. In the laboratory, he proved that foxes could be immunized by oral administration of vaccine. He envisioned delivering such vaccine in baits. However, legal complications of getting permission to try this concept proved difficult and so he worked with two Swiss rabies experts, Franz Steck and Alex Wandeler, who turned George's concept into practical disease control-in fact, their work led to the elimination of fox rabies from Switzerland. Later, after the success of George's concept in Switzerland, France, Germany, Canada and elsewhere, he was vindicated when the oral vaccination of wildlife was introduced into several parts of the United States. For all this, George Baer's name will always be associated with modern wildlife rabies control.

While at the CDC Rabies Laboratory, George also edited the definitive rabies reference book of its day: The
Natural History of Rabies (Volumes I and II; Academic Press, New York, 1975). Later, he produced a second edition, again drawing upon the leading experts to contribute chapters (one volume; CRC Press, Boca Raton, 1991) - there were chapters by Charles Rupprecht, William Wunner, Hilary Koprowski, Pierre Sureau, Pierre Rollin, Charles Trimarchi, John Debbie, W. Gerry Winkler, Suzanne Jenkins, Alex Wandeler, Daniel Fishbein, and many others. George also published widely (more than 100 publications), whether stemming from his own research work or his public health leadership role. Over the years, he also presented many hundreds of seminars, lectures, and workshops throughout the western hemisphere. One can only guess at the numbers, but it is easy to recall their overall impact on the prevention and control of rabies.

After retirement from CDC in August 1991, George founded a successful diagnostic laboratory in Mexico City. At the time of his death, he was working on a new vaccine for influenza, a timely project given the recent threat of pandemic influenza.

The memory of George Baer is being honored in several ways: (1) a memorial symposium at CDC in September 2009 on World Rabies Day; (2) a homage at the annual International Conference on Rabies in the Americas (RITA), and the renaming of an award recognizing the best contribution to become the "George Baer Latin American Investigator Award"; and (3) recognition at a ceremony held at the College of Veterinary Medicine, Cornell University.

On a personal note, George will be remembered for his wonderful evangelical sense of commitment to the cause of disease prevention and control, for the straightforward purpose of improving human wellbeing, globally, and his prescient embrace of the "one health" concept. He often reminded colleagues at the CDC that it is necessary to get out into the parts of the country and the world where diseases, like rabies, are important and where much effort is still needed if we are to substantially affect morbidity and mortality. He often reminded colleagues of his view of the increasing gap between arcane laboratory-based reductionistic research and practical field-based holistic application of widely understood public health strategies. He often reminded colleagues of his view that the balance between these two arms of medical and veterinary science is tipping dangerously away from having immediate impact. His wish was that all of us would understand his viewpoint. A quote from Goethe comes to mind: "Knowing is not enough; we must apply. Willing is not enough; we must do." To say that George will be missed is an understatement-he will not be forgotten. He leaves to us a legacy of enthusiastic commitment to his work and an equal commitment to the application of that work for the benefit of the people of the world. He leaves to us his quick smile and his grand joie de vivre. 